\title{
Tetrahydroxy Flavone from Acacia auriculiformis A. Cunn Ex Benth. (Fabaceae) with Novel Kinase Activity
}

\author{
Augustine A. Ahmadu ${ }^{1,}{ }^{*}$, Bilqis A. Lawal' ${ }^{2}$, Anas Haruna', Lukman Mustapha ${ }^{1}$
}

\section{Augustine A. Ahmadu ${ }^{1, *}$, Bilqis A. Lawal' ${ }^{2}$ Anas Ha- runa', Lukman Mustapha'}

\section{'Department of Pharm and Medicinal} Chemistry, Kaduna State University, Tafawa Balewa Road, Kabala Costain, Kaduna, NIGERIA.

${ }^{2}$ Department of Pharmacognosy and Drug Development, University of Ilorin, Ilorin, Kwara, NIGERIA.

\section{Correspondence}

Augustine A. Ahmadu

Department of Pharm. and Medicinal Chemistry, Kaduna State University, Tafawa Balewa Road, Kabala Costai, Kaduna, NIGERIA.

Phone no: +2348037033505

E-mail: ahmadu2001@yahoo.com

History

- Submission Date: 10-12-2018;

- Review completed: 18-2-2019;

- Accepted Date: 01-04-2019

DOI : 10.5530/pj.2019.11.89

Article Available online http://www.phcogj.com/v11/i3

\section{Copyright}

(C) 2019 Pharmacognosy Journal. This is an open-access article distributed under the terms of the Creative Commons Attribution 4.0 International license.

\begin{abstract}
Background: The decoctions of the bark of Acacia auriculiformis are used in folkloric medicine to relieve pain and inflammation and as remedy for cancer. Objective: The aim of this work is to screen the extract and fractions of Acacia auriculiformis for protein kinase inhibitory activity and also to isolate and characterize chemical entities from this plant and evaluate their protein kinase inhibitory activity. Materials and Methods: Kinase inhibitory activity were assayed in appropriate buffer, with either protein or peptide as substrate in the presence of $15 \mu \mathrm{M}(33-\mathrm{P})$ ATP $(3,000 \mathrm{Ci} / \mathrm{mmol} ; 10 \mathrm{mCi} / \mathrm{ml})$ in a final volume of $30 \mu \mathrm{L}$. Controls were performed with appropriate dilutions of dimethyl sulphoxide. A portion of the Chloroform extract, ethylacetate and n-butanol soluble fractions of the stem bark of Acacia auriculiformis were screened against a panel of disease-related protein kinases and the active fractions was tested over a wide range of concentrations from 0.016 to $50 \mu \mathrm{g} / \mathrm{ml}$ and the $\mid \mathrm{IC}_{50}$ values were determined from the dose response curve. The most active fraction was subjected to chromatographic separation using Silica gel G column chromatography and sephadex LH-20 to give compound I. The structure of the isolated compound was elucidated using NMR and LCMS. Results: The Primary screening of the extract and fractions showed that the chloroform extract was inactive against all the protein kinases investigated, while the ethylacetate and n-butanol soluble fractions inhibited all the protein kinases tested. Compound I also inhibited all the kinases tested. The $I C_{50}$ of the active fractions and compound were also evaluated. Ethylacetate fraction inhibited all the kinases tested with the highest activity against Haspine kinase with $I C_{50}$ of $1.0 \mu \mathrm{g} / \mathrm{ml}$, while n-butanol also gave the highest activity against Haspine kinase with $1 C_{50}^{0}$ of $1.3 \mathrm{\mu g} / \mathrm{ml}$. From the active ethylacetate fractions $3,4^{\prime}, 7$, 8- tetrahydroxy flavone was isolated. The Compound exhibited the maximal activity against DYRK1A kinase with an $\mathrm{IC}_{50}$ of $2.05 \mu \mathrm{g} / \mathrm{ml}$ followed by CDK9 with an $\mathrm{IC}_{50}$ of $2.28 \mu \mathrm{g} / \mathrm{ml}$. Conclusion: $3,4^{\prime}, 7$, 8- tetrahydroxy flavone was isolated was found to be a DYRK1A and CDK9 inhibitor which might justify the anticancer potential of this plant.

Key words: Tetrahydroxyflavone, Protein kinases, CDK9, DYRK1A.
\end{abstract}

\section{INTRODUCTION}

Human protein kinases represent the third largest enzyme class and are responsible for modifying an estimated one-third of human proteome. ${ }^{1}$ It has been firmly demonstrated that hyperactivation, hyperproduction or mutations of these kinases leading to the disruption of cell signalling cascades, play important diabetes among others, thus making protein kinases one of the most important targets for pharmaceutical industry. ${ }^{2}$ The human genome consists of over 517 protein kinases that include two sub families, serine/ threonine and tyrosine kinases. ${ }^{3}$ Numerous tyrosine kinases inhibitors have been discovered by screening plant extracts based on ethnopharmacological and chemotaxonomic knowledge. ${ }^{4}$ Specific screening approach have led to the isolation of structurally distinct classes of inhibitors which have served as leads role in several diseases such as cancer, inflammation, for further design and synthesis of more active analogues.

Acacia is quite a large genus of the family fabaceae, with about 1,400 species. Most of the species belonging to the genus are rich in secondary metabolites containing mainly tannins, flavonoids and gums and is widely distributed in tropical and non tropical countries including Nigeria.

Acacia auriculiformis also referred to as ear leaf Acacia is an important medicinal plant and widely distributed member of the fabaceae. An infusion of the bark of this plant is used to treat inflammation among the aborigines of Australia. ${ }^{6}$ The antimutagenic and chemoprotective activities of extracts of the stem bark of Acacia auriculiformis have been reported. ${ }^{7}$ The antioxidant and free radical scavenging properties of the ethylacetate and acetone fraction of the stem bark of this plant have been
Cite this article: Ahmadu AA, Lawal BA, Haruna A, Mustapha L. Tetrahydroxy Flavone from Acacia auriculiformis A. Cunn Ex Benth. (Fabaceae) with Novel Kinase Activity. Pharmacog J. 2019;11(3):559-63. 
reported. ${ }^{89}$ A new triterpenoid trisaccharide and three new triterpenoids have been isolated from this plant. ${ }^{10,11}$ The antimicrobial activity of saponins and a new flavan glycoside have been reported from this plant. ${ }^{12,13}$ Previously, we have reported the protein kinase inhibitory activity of Acanilol 2, a new Peltogynoid isolated from the bark of Acacia nilotica ${ }^{14}$ and recently, we also reported that the ethylacetate soluble fraction and two compounds isolated from the fraction inhibited a panel of protein kinases and $(+)$-catechin showed tissue necrosis of some tumoral cell. ${ }^{15}$ In our continuing investigation of the genus acacia for protein kinase inhibitory constituents, we report herein the activity of the extract, fractions and the isolated flavonoid from the active ethylacetate soluble fraction of the stem bark of Acacia auriculiformis against a panel of some disease related protein kinases.

\section{MATERIALS AND METHODS}

\section{General experimental procedures}

Column chromatography was performed on silica gel G (200-400 mesh, Silicycle), Thin layer chromatography was performed on pre-coated TLC plate silica gel $0.2 \mathrm{~mm}$ aluminium backed (Silicycle), NMR spectra was performed on a Bruker DRX $400 \mathrm{MHz}$ spectrophotometer in $\mathrm{CD}_{3} \mathrm{OD}$ using TMS as internal standard, while LC-MS was carried out using an ESI-LTQ-orbitrap discovery XL mass spectrometry.

\section{Plant material}

The plant consisting of the leaves and stem bark were collected in Zaria in the month of July and were authenticated at the herbarium section of the Biological Science Department, Ahmadu Bello University, Zaria, where a voucher specimen was deposited.

Extraction and isolation

The dried pulverised stem bark (400 g) was extracted with chloroform (2X2L) at room temperature and the solvent removed at reduced pressure to give a $0.6 \mathrm{~g}(2.4 \%)$ of chloroform extract. The marc was then extracted to exhaustion with $70 \%$ ethanol to give a brown solid mass of ethanol extract $47 \mathrm{~g}(11.8 \%)$. A portion of the ethanol extract $27 \mathrm{~g}$ was suspended in $300 \mathrm{ml}$ of distilled water and successfully extracted with $50 \mathrm{mlx} 8$ of ethylacetate and $50 \mathrm{mlx} 8$ of $\mathrm{n}$-butanol and removal of the solvents at reduced pressure afforded a dark brown solid mass $(3.5 \mathrm{~g})$ of ethylacetate fraction and a brown sold mass of n-butanol fraction which weighed $5.4 \mathrm{~g}$. A portion of the chloroform, ethylacetate and n-butanol fractions were investigated for protein kinase activity against a panel of diseased related protein kinases.

The active ethylacetate fraction ( $2 \mathrm{~g}$ ) was packed in a column of $(3 \mathrm{~cm} \times 50 \mathrm{~cm})$ and elution commenced gradiently with $\mathrm{n}$-hexane and n-hexane dichloromethane mixtures followed with dichloromethane and dichloromethane: methanol mixtures. The progress of elution was monitored on thin layer chromatography using the solvent systems I and II which consists of ethyl acetate: dichloromethane: methanol: water (15:8:4:1) and ethyl acetate: dichloromethane (1:1) respectively. Fractions eluted with $5 \%$ methanol in dichloromethane which were homogenous on TLC plates were pooled together and purified over sephadex LH-20 eluting with methanol to afford compound I, a yellow solid (3mg).

The compound was identified by spectroscopic data $\left({ }^{1} \mathrm{H},{ }^{13} \mathrm{C}\right.$ and $\left.\mathrm{MS}\right)$ and comparison with literature.

\section{Protein kinase inhibitory studies}

A portion of the chloroform, ethylacetate and n-butanol fractions and compound I were screened against a panel of diseased related protein kinases. Kinase activity were assayed in appropriate buffer, with either protein or peptide as substrate in the presence of $15 \mu \mathrm{M}\left({ }^{33}-\mathrm{P}\right)$ ATP $(3,000 \mathrm{Ci} / \mathrm{mmol} ; 10 \mathrm{mCi} / \mathrm{ml})$ in a final volume of $30 \mu \mathrm{L}$ following the assay as described. ${ }^{16}$ Controls were performed with appropriate dilutions of dimethyl suphoxide. Full length Kinases were used unless specified. Peptide substrates were obtained from Proteogenix (Oberhausbergen, France).

\section{Buffers}

A $10 \mathrm{mM} \mathrm{MgCl}$, 1mM EGTA, 1mM DTT, 25 mM Tris- $\mathrm{HCl}$ pH7.5,50 $\mu \mathrm{g} / \mathrm{ml}$ heparin.

B $60 \mathrm{mM} \beta$-glycerophosphate, 30mM p-nitrophenyl-phosphate, $25 \mathrm{mM}$ MOPS (pH7), 5mM EGTA, $15 \mathrm{mM} \mathrm{MgCl}, 1 \mathrm{mM}$ DTT, $0.1 \mathrm{mM}$ sodium orthovanadate.

(D) $25 \mathrm{mM}$ MOPS, pH7.2, $12.5 \mathrm{mM} \beta$-glycerophosphate, $25 \mathrm{mM} \mathrm{MgCl}_{2}$, 5mM EGTA, 2mM EDTA, 0.25 mM DTT.

(H) MOPS 25mM pH 7.5, $10 \mathrm{mM} \mathrm{MgCl}_{2}$

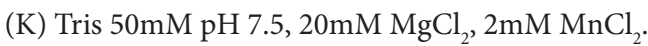

(R) $5 \mathrm{mM}$ MOPS $\mathrm{pH} 7.2,2.5 \mathrm{mM} \beta$-glycerophosphate, $4 \mathrm{mM} \mathrm{MgCl}_{2}$, $2.5 \mathrm{~mm} \mathrm{MnCl}_{2}, 1 \mathrm{mM}$ EGTA, $0.4 \mathrm{mM}$ EDTA,50 $\mu \mathrm{g} / \mathrm{ml} \mathrm{BSA}, 0.05 \mathrm{mM}$ DTT.

Hs CDK2/Cyclin A (cyclin-dependent kinase-2, human, kindly provided by Dr. A. Echalier-Glazer, Leicester, UK) was assayed in buffer A $(+0.15 \mathrm{mg} / \mathrm{mL}$ of BSA $+0.23 \mathrm{mg} / \mathrm{mL}$ of DTT $)$ with $0.8 \mu \mathrm{g} / \mathrm{mL}$ of histone $\mathrm{H} 1$ as substrate.

HsCDK9/Cyclin T (human, recombinant, expressed by baculo virus in S19 insect cells was assayed in buffer A $(+0.15 \mathrm{mg} / \mathrm{ml}$ of BSA $+0.23 \mathrm{mg} /$ $\mathrm{ml}$ of DDT) with $0.27 \mu \mathrm{g} / \mathrm{mL}$ of the following peptide: YSPTSPSYSPTSPSYSPTSPSKKKK, as substrate.

HsCDK5/p25 (human, recombinant, expressed in bacteria) was assayed in buffer $\mathrm{B}$, with $0.8 \mu \mathrm{g} / \mu \mathrm{L}$ of histone $\mathrm{H} 1$ as substrate.

HsPIM1 (human proto-oncogene, recombinant, expressed in bacteria) was assayed in buffer B, $0.8 \mu \mathrm{g} / \mu \mathrm{L}$ of histone H1 (Sigma \#H5505) as substrate.

HsHaspin-kd (human, kinase domain, amino acids 470 to 798 , recombinant, expressed in bacteria) was assayed in buffer $\mathrm{H}$ with $0.007 \mu \mathrm{g} /$ $\mu \mathrm{L}$ of Histone H3 (1-21) peptide (ARTKQTARKSTGGKAPRKQLA) as substrate.

HsRIPK3 (human, recombinant, expressed in Sf9 insect cells) was assayed in buffer $\mathrm{R}$ with $0.1 \mu \mathrm{g} / \mu \mathrm{L}$ of MBP as substrate.

HsAuroraB (human, recombinant, expressed by baculovirus in S19 insects' cells, Signal Chem, product \#A31-10G) was assayed in buffer D with $0.2 \mu \mathrm{g} / \mu \mathrm{L}$ of $\mathrm{MBP}$ as substrate.

SscGSK-3 $\alpha, \beta$ (glycogen synthase kinase-3, porcine brain, native, affinity purified) was assayed in buffer A $(+0.15 \mathrm{mg} / \mathrm{mL}$ of BSA $+0.23 \mathrm{mg} / \mathrm{mL}$ of DTT ), with $0.010 \mu \mathrm{g} / \mu \mathrm{L}$ of GS-1 peptide, a GSK-3 selective substrate (YRRAAVPPSPSLSRHSSPHQSpEDEEE, sp satands for phosphorylated serine).

SscCK1 $\delta / €$ (casein kinase $1 \delta / €$, porcine brain, native, affinity purified) was assayed in buffer $B$, with $0.022 \mu \mathrm{g} / \mu \mathrm{L}$ of the following peptide: RRKHAAIGSpAYSITA as CK1 -specific substrate).

RnDYRK1A-kd (Rattus norvegicus, amino acids 1 to 499 including the kinase domain, recombinant, expressed in bacteria, DNA vector provided by Dr W. Becker, Aachen, Germany) was assayed in buffer A (+0.5 $\mathrm{mg} / \mathrm{mL}$ of BSA $+0.23 \mathrm{mg} / \mathrm{mL}$ of DTT) with $0.033 \mu \mathrm{g} / \mu \mathrm{L}$ of the following peptide :KKISGRLSPIMTEQ as substrate.

MmCLK1 (from Mus musculus, recombinant, expressed in bacteria) was assayed in buffer A $(+0.15 \mathrm{mg} / \mathrm{ml}$ of BSA $+0.23 \mathrm{mg} / \mathrm{ml}$ of DTT) with $0.027 \mu \mathrm{g} / \mu \mathrm{L}$ of the following peptide: GRSRSRSRSRSR as substrate.

PfGSK-3 (from Plasmodium falciparum, recombinant, expressed in bacteria) was assayed in Buffer A $(+0.15 \mathrm{mg} / \mathrm{mL}$ of BSA $+0.23 \mathrm{mg} / \mathrm{mL}$ of DTT) with $0.010 \mu \mathrm{g} / \mu \mathrm{L}$ of GS-1 peptide, a GSK-3-selective substrate 
(YRRAVPPSPSLSRHSSPHQSpEDEEE, sp stands for phosphorylated serine).

LdTLK (tousled -like kinase, from Leishmania donovani, recombinant, expressed in bacteria), was assayed in buffer $\mathrm{K}$ with $0.6 \mu \mathrm{g} / \mu \mathrm{L}$ of casein dephosphorylated from bovine milk (Sigma \#C4032) as substrate.

LmCK1 (from Leishmania major, recombinant, expressed in bacteria was assayed in buffer B (adjusted at $\mathrm{pH}$ 8) with $0.028 \mu \mathrm{g} / \mu \mathrm{L}$ of the following peptide: RRKHAAIGSpAYSITA as CK1-specific substrate.

\section{RESULTS}

Compound 1 was isolated as a yellow solid $(3 \mathrm{mg})$. Its spectral data $\left({ }^{1} \mathrm{H}\right.$,NMR and LC-MS) are consistent with literature data for 3, 4, 7,8 -tetrahydroxyflavone.

\section{Effects of the extract/fractions on the activity of disease- related protein kinases}

Table 1 show the results of the primary screening of the chloroform extract, ethyl acetate-n-butanol soluble fractions and compound I against a panel of protein kinases. The result indicates the activity that remains in the tube after treating the mentioned kinase with $50 \mu \mathrm{g} / \mathrm{mL}$ of the extract/fraction compared to control assay treated with DMSO. The result revealed that the chloroform extract showed the least activity against the kinases as the extract did not inhibit the activity of the kinases and hence the high \% activity of each kinase remaining in the tube this can be observed on the activity of the extract against Pim1 which showed $91 \%$ of the activity of the kinase still remaining in the tube after treatment with $50 \mu \mathrm{g} / \mathrm{mL}$ of the extract in comparison with the control. The ethyl acetate and n-butanol fractions in contrast, however showed a reduction in kinase activity in the tube after treating the mentioned extract with $50 \mu \mathrm{g} / \mathrm{mL}$ of the fraction. In Table 1, the ethyl acetate fraction on Pim 1 showed only $2 \%$ of remaining activity of the kinase in the tube compared to DMSO. A similar trend was observed in n-butanol fraction. The isolated flavonoid also shows some inhibitory activity against all the kinases tested. The ethyl acetate, $\mathrm{n}$-butanol fractions and compound I were next evaluated over a wide range of concentrations from $0.016 \mu \mathrm{g} / \mathrm{mL}$ to $50 \mu \mathrm{g} / \mathrm{mL}$ and $\mathrm{IC}_{50}$ values were determined from the dose response curves (Sigma-plot). The results of the in vitro enzymatic activity assay were summarised in Table 2 .

Table 2 shows the inhibitory activity of the ethylacatetate, n-butanol fractions and isolated flavonoid against the mentioned kinases with their $\mathrm{IC}_{50}$. The result revealed that the ethylacetate fraction is the most active with $\mathrm{IC}_{50}$ of $1.0 \mu / \mathrm{mL}$ against Haspine kinase followed with Hs CDK9 with an $\mathrm{IC}_{50}$ of $4.5 \mu \mathrm{g} / \mathrm{mL}$. The activity of the ethylacetate fraction is more than n-butanol fraction.

\section{DISCUSSION}

Compound 1 was isolated as a yellow solid, its mass spectral data gave a molecular ion peak at $\mathrm{m} / \mathrm{z} 286$ that depict a molecular formula

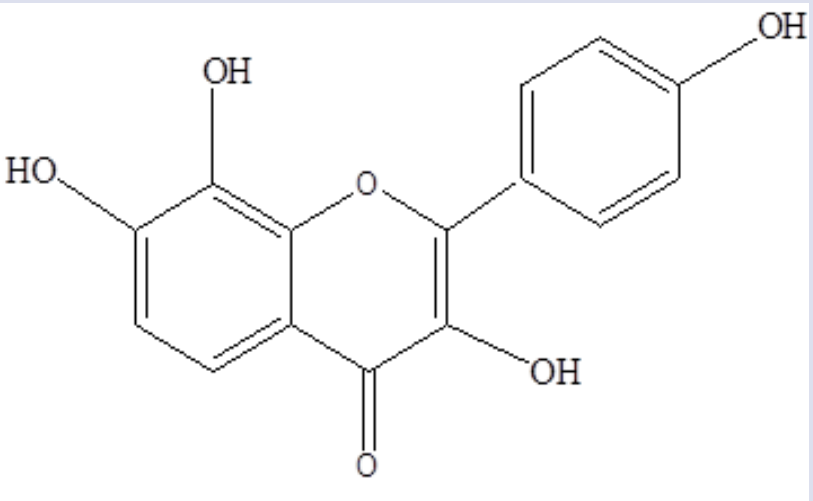

Figure 1: Compound I.

Table 1: Primary screening of extract/fractions of A. auriculiformis against 14 disease-related protein kinases\#.

\begin{tabular}{cccccccccccccc}
\hline Extract & Cdk2 & Cdk5 & Cdk9 & CLK1 & GSK3 & Dyyrk1A & PIM1 & Haspine & RIPK3 & mCLK1 & LdTLK & CK1 & AuroraB \\
\hline CHCl $_{3}$ & 110.0 & 106.0 & 105.0 & 70.0 & 65.0 & 91.0 & 90.0 & 77.0 & 113.0 & 84.0 & 96.0 & 73.0 & 116.0 \\
ETOAc & 10.0 & 13.0 & 9.0 & - & 4.0 & - & 2.0 & 2.0 & 31.0 & 28.0 & 52.0 & - & 30.0 \\
n-Butanol & 39.0 & 39.0 & 14.0 & - & 21.0 & - & 2.0 & 6.0 & 19.0 & 48.0 & 45.0 & - & 12.0 \\
Compound 1 & - & 29.0 & 14.0 & 16.0 & 32.0 & 11.0 & 10.0 & 24.0 & - & 22.0 & - & - & - \\
\hline
\end{tabular}

\#Indicates the results of the primary screening performed using $50 \mu \mathrm{g} / \mathrm{ml}$ of the extract, fractions and isolated compound. Data are expressed in $\%$ maximal activity i.e measured in the absence of the inhibitor. ATP concentration used in the kinase assays was $15 \mu$ mol/L (values are means, $\mathrm{n}=2$ ). Kinases are from human origin unless specified: Ssc, Sus scrofa; Rn, Rattus norvegicus; Mm, Mus musculus; Pf, Plasmodium falciparum; Lm, Leishmania major; Ld, Leishmania donovani. (-) not tested

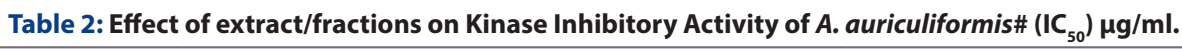

\begin{tabular}{ccccccccccccc}
\hline Extract & Cdk2 & Cdk5 & Cdk9 & CLK1 & GSK3 & DYyrk1A & PIM1 & Haspine & RIPK3 & CK1 & HsAuroraB \\
\hline ETOAC & 7.5 & 6.0 & 4.5 & - & 9.0 & - & 5.0 & 1.0 & 30.0 & 30.0 & 5.0 \\
n-Butanol & 45.0 & 52.0 & 17.5 & - & 15.0 & - & 20.0 & 1.3 & 17.5 & 25.0 & 5.0 \\
Compound 1 & - & $>50$ & 2.28 & 9.99 & 8.45 & 2.05 & 30.1 & $>50$ & - & 25.0 & - \\
\hline
\end{tabular}

\#Values reported in the are a mean of $n=3$ independent experiments. ATP concentration used in the kinase assays was $15 \mu \mathrm{mol} / 1$. Kinases are from human origin unless specified : Ssc, Sus Scrofa; Rn, Rattus norvegicus; Mm, Mus musculus; Pf, Plasmodium falciparum; Lm, Leishmania major; Ld, Leishmania donovani. (-) not tested. 
$\mathrm{C}_{15} \mathrm{H}_{10} \mathrm{O}_{6}$ suggestive of a mono flavonoid nucleus (Figure 1). The proton NMR revealed a tetrahydroxy substituted flavonoid nucleus showing a monosubstituted ring B and a 7,8-dihydroxysubstituted ring A flavonoid nucleus respectively, this depict compound 1 to be 3,4,7,8-tetrahydroxy flavone (Figure 1), the spectra compares well with literature. ${ }^{17}$ This is the first report of this flavonoid from Acacia auriculiformis. This compound has been isolated previously from Acacia rhodoxylon. ${ }^{18}$ Primary screening of the isolated compound against eight disease related protein kinases (Table 1 ) indicates that the compound inhibited more than $50 \%$ activity of all the kinases, for example against DYRK1A and PIM 1 kinases, the compound inhibits $89 \%$ and $90 \%$ total kinase activity respectively. Table 2 shows the $\mathrm{IC}_{50}$ values for compound 1 when tested over a wide range concentration from 0.016 to $50 \mu \mathrm{g} / \mathrm{ml}$. The table reports the inhibitory activity of the compound against the mentioned kinases. The compound was active against six out of 8 kinases tested; however, the compound was found to be inactive against Haspine and CDK5 kinases, the $\mathrm{IC}_{50}$ values of the compound against DYRKIA and CDK9 was estimated at 2.05 and $2.28 \mu \mathrm{g} / \mathrm{ml}$ respectively indicating that the isolated flavonoid is a DYRK1A and CDK9 inhibitor.

Flavonoids have been shown to have the ability to modify or modulate the activities of some enzymes involved in cell surface signal transduction, immune function and transformation, tumor growth and metastasis. ${ }^{19,20}$ The inhibitory effect of flavonoids in growth of malignant cells could be a consequence of their interference with protein kinase activities involved in the regulation of cellular proliferation and apoptosis. ${ }^{21}$

\section{CONCLUSION}

The ethylacetate of fraction of Acacia auriculiformis was shown to be the most active among the three extract/fractions investigated for protein kinase inhibitory activity and from the ethylacetate fraction, 3, 4, 7, 8-tetrahydroxyflavone was isolated and was found to be a DYRK1A and CDK9 inhibitor. This result might justify the cancer and inflammation potentials of this plant.

\section{ACKNOWLEDGEMENT}

The authors thank Tertiary Education Trust Fund (TETFUND) for grant support to A. A Ahmadu. The authors wish to thank Dr Stephane Bach of Protein Phosphorylation and Human Disease Laboratory, KISSf screening facility Roscoff France for protein kinase screening and Dr Nikolas Fokialakis of National Kapodistrian University of Athens, Greece for NMR and LC-MS of the isolated compound.

\section{CONFLICT OF INTEREST}

The authors declared no conflict of interest associated with this work.

\section{ABBREVIATIONS}

CD3OD: Deutirated methanol; DMSO: Dimethyl Sulphoxide; LC-MS: Liquid Chromatography-Mass Spectrometry; MCi: MilliCurie; MS:
Mass Spectrometry; NMR: Nuclear Magnetic Resonance; TLC: Thin Layer Chromatography.

\section{REFERENCES}

1. Manning G, Whyte DB, Martinez R, HunterT, Sudarsanam S. The protein kinase Complement of the human genome. Science. 2002;298(5600):1912-34.

2. Levitzki A. Protein kinase inhibitors as a therapeutic modality. Acc Chem Res. 2003;36(6):463-9

3. Capedeville R, Burchdurger E, Zinnermann J and Matter A. Gilvec (Imatinib), a rationally developed target anticancer drug. Nat.Rev Drug Disc 2002; 1:493.

4. Hollosyl F, Keri G. Plant derived protein tyrosine kinase inhibitors as anti-cancer agents. Curr Med Chem. 2004;4(2):173-7.

5. Seigler DS. Phytochemistry of Acacia-Sensu lato. Biochem Syst Ecol. 2003;31(8):845-73.

6. Gijasahnkar V. Micropropagation of multipurpose medicinal tree: Acacia auriculiformis. J Med Plant Res. 2010;5(3):482-6.

7. Kauer K, Aroara S, Hawthone ME, Kauer S, Kumar S, Mehta R. A correlative effect of anti-mutagenic and chemopreventive effect activity of $A$. auriculiformis and A. nilotica. Chem Toxicol. 2002;25(1):639-48.

8. Singh R, Singh S, Kumar S, Arova S. Evaluation of antioxidant potential of ethylacetate fraction of Acacia auriculiformis, A Cunn. Food Chem Toxicol. 2007;45(7):216-23.

9. Singh, R, Singh S, Kumar S, Arova S. Free radical scavenging activity of the acetone extract of Acacia auriculiformis. Food Chem. 2007;103(4):1403-5.

10. Mahato SB, Pal BC, Price KK. Structure of acaccioaside a triterpenoid trisaccharide from the seeds of Acacia auriculiformis. Phytochem. 1989;28(1):207-1.

11. Saraswat G, Mahato SB. Isolation and structure elucidation of three new triterpenoid saponins from Acacia auriculiformis. Phytochem. 1997;44(1):137-40.

12. Mandal P, Sinhababbu SP, Mandal NC. Antimicrobial activity of saponins from Acacia auriculiformis. Fitoterapia. 2005;76(5):462-5.

13. Raghvendra S, Agrwal SK, Rastogi RP. A new flavan glycoside from Acacia auriculiformis. Phytochem. 1982;12(7):1550-5.

14. Ahmadu AA, Agunu A, Grougnet R, Myrianthopoulos $V$, Tilequin F, Magiatis $P$, et al. Two New Peltogynoids from Acacia nilotica with Kinase inhibitory activity. Planta Med. 2009;76(5):458-60.

15. Ahmadu AA, Agunu A, Thi-Ngoc DN, Baratte B, Beatrice FJ, Sandrine R, et al. Constituents of Acacia nilotica L. Delile with novel Kinase inhibitory activity. Planta Med Int Open. 2007;4:e108-13

16. Bach S, Knockaert M, Reinhardt J, Lozach O, Scmitt S, Baratte B, et al Roscovitine targets, protein kimnases and pyridoxal kinase. J of Bio Chem. 1985;280(35):31208-19.

17. Jeon WK, Lee HJ, Kim KH, Lee AY, Lee OS, Ryu SH, et al. Antiplatelet effects of bioactive compounds isolated from the bark of Rhus verniciflua. J of Ethnopharmacol. 2006;106(1):62-9.

18. Clarke-Lewis JW, Dainis I. Flavonoids from the heart wood of Acacia Rhodxylon maden. Aust Journ of Chem.1967;20:2991-4.

19. Huang YT, Hwang JT, Lee JT, Ke PP, Huang FC, Huang TH, et al. Effects of luteolin and quercetin, ihibitors of Tyrosine kinase. Brit J of Pharmacol. 1999;128(5):9991010.

20. Middleton E, Kandaswani C, Theohardis TC. The impact of plant Flavonoids An implication for inflammation, heart disease and cancer. Pharmacol Rev. 2000;52(4):673-9.

21. Akiyama T, Ishida J, Nakagawe $S$, Ogawen H, Watanabe $S$, Hoh N, et al. Genistein, a specific inhibitor of Tyrosine kinase. J Biol Chem. 1987;262(12):5592-5. 
GRAPHICAL ABSTRACT

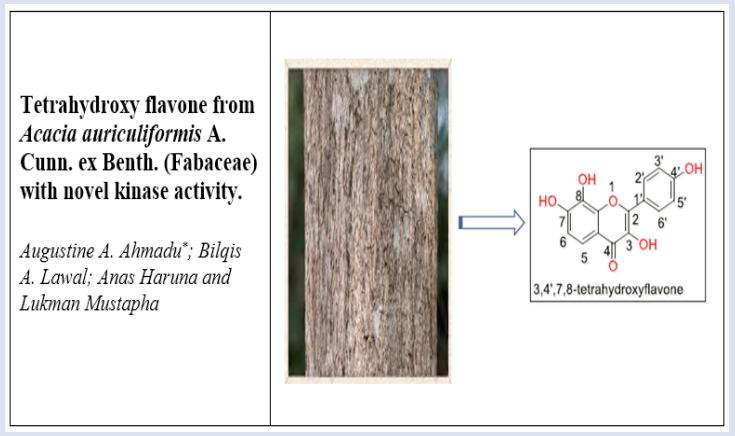

\section{SUMMARY}

- The Chloroform extract, ethylacetate and n-butanol soluble fractions of the stem bark of Acacia auriculiformis A. Cunn. Ex Benth were screen for primary activity against disease related protein kinases. The Chloroform extract was found to be inactive, while both the ethylacetate and n-butanol soluble fractions inhibited all the kinases tested. The $\mathrm{IC}_{50}$ for both the ethylacetate and n-butanol fractions were also investigated. The ethylacetate fraction exhibited the highest activity against Haspine kinase with $I_{50}$ of $1.0 \mu \mathrm{g} / \mathrm{ml}$, while the $\mathrm{n}$-butanol also gave the highest activity against Haspine kinase with IC50 of $1.3 \mu \mathrm{g} / \mathrm{ml}$. From the ethylacetate fractions 3, 4', 7, 8-tetrahydroxyflavone was isolated. The compound exhibited the maximal activity against DYRK1A kinase with an $\mathrm{IC}_{50}$ of $2.05 \mu \mathrm{g} / \mathrm{ml}$ followed by CDK9 with IC $\mathrm{I}_{50}$ of $2.28 \mu \mathrm{g} / \mathrm{ml} .3,4$ ',7,8-tetrahydroxy flavone isolated for the first time from this plant was found to be a DYRK1A and CDK9 inhibitor which might justify the anticancer potentials of this plant.

Cite this article: Ahmadu AA, Lawal BA, Haruna A, Mustapha L. Tetrahydroxy Flavone from Acacia auriculiformis A. Cunn Ex Benth. (Fabaceae) with Novel Kinase Activity. Pharmacog J. 2019;11(3):489-93. 